\title{
COMMENTARY
}

\section{Right man, right time, right place? - On the time course of the mediator orchestra in septic shock}

\author{
Balázs Hauser*1 and Peter Radermacher ${ }^{2}$ \\ See related research by Lange et al., http://ccforum.com/content/14/4/R129
}

\begin{abstract}
Appropriate timing of treatment assumes particular importance in critical care. Lange and colleagues recently reported on the time course of the different nitric oxide synthase (NOS) isoforms, nitrosative stress, and poly(ADP-ribosylation) during Pseudomonas aeruginosa pneumonia-induced ovine septic shock. Initially, endothelial NOS expression was increased together with markers of peroxynitrite formation, DNA damage, and nuclear factor-kappa-B activation. Later on, measurable NOS activity and nitric oxide production resulted mainly from inducible NOS activation. These results emphasize the need for longterm, large-animal studies investigated over days so that future therapeutic interventions can be better tailored and matched to the exact time course of the activation of the mediator orchestra.
\end{abstract}

Timing is everything! Appropriate timing of treatment is the key to successful intensive care; treatment that is delayed could be as detrimental as treatment that is premature. Therefore, Lange and colleagues [1], in this issue of Critical Care, reported on the time course of the expression of the different isoforms of the nitric oxide synthase (NOS) - that is, neuronal NOS [nNOS], inducible NOS [iNOS], and endothelial NOS [eNOS] (also known as NOS1, NOS2, and NOS3, respectively) of the tissue levels of nitrotyrosine and poly(ADP-ribose), markers of nitrosative stress, and DNA damage resulting from peroxynitrite formation as well as p65, a mirror of the activation of the nuclear factor-kappa-B (NF-kB), in a well-established resuscitated ovine model of septic shock induced by Pseudomonas aeruginosa pneumonia.

\footnotetext{
*Correspondence: bhauser1@gmail.com

'Aneszteziológiai és Intenzív Terápiás Klinika, Semmelweis University,

H-1125 Budapest, Kútvölgyi út 4. Hungary

Full list of author information is available at the end of the article
}

'Downstream effects' were evaluated by measuring NOS activity, nitric oxide $(\mathrm{NO})$ production, and interleukin- 8 concentrations. During the early phase (that is, 4 to 12 hours after induction of pneumonia), eNOS expression was increased, and this coincided with increased tissue levels of nitrotyrosine, poly(ADP-ribose), and NF- $\mathrm{kB}$ activation, whereas in the later phase (that is, until 24 hours of pneumonia), measurable NOS activity and NO production were related mainly to iNOS activation. The authors' 'two-hit' model of cotton smoke inhalation and subsequent instillation of live bacteria is characterized by a hyperdynamic circulation, hypotension, tissue acidosis, and progressive impairment of gas exchange, lung mechanics, and morphological alterations typical of acute lung injury. Furthermore, the model comprises resuscitation measures and thus allows the study of pathophysiological pathways in a clinically relevant, large-animal setting.

Numerous studies evaluated the NO-related mediator orchestra and highlighted the friend-and-foe character of excess NO formation [2]: NO not only is well established as a reactive nitrogen species (RNS), often referred to as a 'final mediator' of sepsis-induced hypotension, but also acts as a scavenger of reactive oxygen species (ROS), such as the superoxide radical. This reaction, however, leads to the formation of the even more toxic peroxynitrite, which ultimately results in protein nitrosylation, DNA damage, and activation of poly(ADP-ribose) polymerase (PARP) [3]. Finally, the NO production rate depends on the stimulus and the species, and therefore rodent data cannot be transferred directly to the clinical scenario [4]. Endogenous NO production in large animals is much closer to that of human beings, but although increased NO production during sepsis is well established [2], these models yielded controversial results [5]. The early and transient (within minutes) activation of PARP [3] would make PARP inhibition an attractive approach, but unfortunately medical care is usually not available during this very early phase. Moreover, the pathophysiological consequences of PARP-1 activation are opposed to its vital role in the maintenance of genomic integrity through its function in base excision repair, and the 
effects of PARP inhibition on DNA damage and repair during shock are still a matter of debate [6,7]. Therefore, PARP inhibitors are currently investigated in ischemiareperfusion, oncology, and diabetes rather than in sepsis or acute lung injury, and peroxynitrite-neutralizing agents are a tempting alternative $[3,8]$. Several studies explored the potential of selective inhibition of NOS isoforms under the assumptions that nNOS and eNOS are constitutively producing homeostatic NO and that iNOS responds to acute stimuli with excessive NO production [2,5]. In fact, the crucial role of eNOS expression seems to be unequivocal: eNOS activation improved microvascular perfusion [9] and cardiac function [10] in rodents, and eNOS polymorphism was associated with hypotension during human Gramnegative sepsis [11]. Clearly, iNOS still seems to be a 'bad guy': several studies showed beneficial effects of various selective iNOS inhibitors on hemodynamics, lung function, deranged microcirculatory perfusion, coagulation disorders, and visceral organ injury [12-14]. Recent data, however, suggest that nNOS activation may also assume major importance [15], and a combined approach using selective nNOS inhibition during the early phase (0 to 12 hours) and iNOS inhibition during the later phase (12 to 24 hours) yielded improved pulmonary function and attenuated nitrosative stress [16]. Finally, selective iNOS inhibition together with the ROS scavenger tempol also afforded significant protection, further emphasizing the close interaction of $\mathrm{NO}$ and oxidative/nitrosative stress [17]. Despite these encouraging results, nothing is simple or easy: in resuscitated murine septic shock, both genetic deletion and selective pharmacologic blockade of the iNOS were associated with markedly improved systolic contraction and catecholamine responsiveness but simultaneously deteriorated diastolic relaxation [18].

What can we learn from the study by Lange and colleagues [1]? Unfortunately, the authors did not report data on oxidative stress, so a complete overview of the whole RNS- and ROS-related mediator orchestra is only implicitly provided. Nevertheless, the authors add an important piece to the complex puzzle of the NO-related pathophysiological pathways: nitrosative stress (that is, increased nitrotyrosine and poly[ADP-ribose] levels) was aggravated only during the early phase up to 12 hours, whereas clear-cut increases in NOS activity, NO metabolites, and subsequently cytokines occurred only later on. Interestingly, in this experiment, in contrast to previous reports from the same group, nNOS synthesis was not increased. Finally, despite its inherent protective properties, eNOS activation was also involved in the initiation of the septic response, and it remains to be elucidated whether this mirrors an adaptive or pathologic mechanism.
How can we translate these data to daily care? Usually, there are few chances to intervene during the very early, evolving phase of sepsis and acute lung injury, and at the time of full-blown sepsis, all members of the mediator orchestra are already playing their (un)coordinated, and unfortunately sometimes uncontrollable, concert. There are two ways to go from here, and both are worthy of being followed! First, though extremely time- and resource-consuming, long- or longer-term large-animal models with a more prolonged observation period (that is, days) are needed and will probably yield valuable clues to the design of clinical studies. Second, more studies on humans are warranted in order to better describe early and later phases of human sepsis in terms of NOS, peroxynitrite formation, and PARP activation. These data might provide further evidence for drug and study design in the future. Lange and colleagues have the merit of having given the starting signal.

\begin{abstract}
Abbreviations
eNOS, endothelial nitric oxide synthase; iNOS, inducible nitric oxide synthase; NF-KB, nuclear factor-kappa-B; nNOS, neuronal nitric oxide synthase; NO, nitric oxide; NOS, nitric oxide synthase; PARP, poly(ADP-ribose) polymerase; RNS, reactive nitrogen species; $R O S$, reactive oxygen species.
\end{abstract}

\section{Competing interests}

The authors declare that they have no competing interests.

\section{Author details}

${ }^{1}$ Aneszteziológiai és Intenzív Terápiás Klinika, Semmelweis University, H-1125 Budapest, Kútvölgyi út 4. Hungary. ${ }^{2}$ Sektion Anästhesiologische Pathophysiologie und Verfahrensentwicklung, Klinik für Anästhesiologie, Universitätsklinikum, Parkstrasse 11, D-89073, Ulm, Germany.

Published: 23 August 2010

\section{References}

1. Lange M, Connelly R, Traber DL, Hamahata A, Nakano Y, Esechie A, Jonkam C, von Borzyskowski S, Traber LD, Schmalstieg FC, Herndon DN, Enkhbaatar P: Time course of nitric oxide synthases, nitrosative stress, and poly(ADP ribosylation) in an ovine sepsis model. Crit Care 2010, 14:R129.

2. Hollenberg SM, Cinel I: Bench-to-bedside review: nitric oxide in critical illness - update 2008. Crit Care 2009, 13:218.

3. Szabó C, Modís K: Pathophysiological roles of peroxynitrite in circulatory shock. Shock 2010 Jun 22. [Epub ahead of print].

4. Reade MC Young JD: Of mice and men (and rats): implications of species and stimulus differences for the interpretation of studies of nitric oxide in sepsis. Br J Anaesth 2003, 90:115-118.

5. Hauser B, Bracht H, Matejovic M, Radermacher P, Venkatesh B: Nitric oxide synthase inhibition in sepsis? Lessons learned from large animal studies Anesth Analg 2005, 101:488-498.

6. Hauser B, Gröger M, Ehrmann U, Albicini M, Brückner UB, Schelzig H, Venkatesh B, Li H, Szabó C, Speit G, Radermacher P, Kick J: The PARP-1 inhibitor INO1001 facilitates hemodynamic stabilization without affecting DNA repair in porcine thoracic aortic cross-clamping induced ischemia/ reperfusion. Shock 2006, 25:633-640.

7. Gerö D, Szabó C: Poly(ADP-ribose) polymerase: a new therapeutic target? Curr Opin Anaesthesiol 2008, 21:111-121.

8. Maybauer DM, Maybauer MO, Szabó C, Cox RA, Westphal M, Kiss L, Horvath E, Traber LD, Hawkins HK, Salzman AL, Southan GJ, Herndon DN, Traber DL: The peroxynitrite catalyst WW-85 improves pulmonary function in ovine septic shock. Shock 2010 Jun 22. [Epub ahead of print].

9. McGown CC, Brown NJ, Hellewell PG, Reilly CS, Brookes ZL: Beneficial microvascular effects of pravastatin during sepsis involve nitric oxide synthase III. Br J Anaesth 2010, 104:183-190. 
10. Bougaki M, Searles RJ, Kida K, De Yu J, Buys ES, Ichinose F: NOS3 protects against systemic inflammation and myocardial dysfunction in murine polymicrobial sepsis. Shock 2009 Dec 7. [Epub ahead of print].

11. Huttunen R, Hurme M, Laine J, Eklund C, Vuento R, Aittoniemi J, Huhtala H, Syrjänen J: Endothelial nitric oxide synthase G894T (GLU298ASP) polymorphism is associated with hypotension in patients with $\mathrm{E}$. coli bacteremia but not in bacteremia caused by gram-positive organism. Shock 2009, 31:448-453.

12. Matejovic M, Krouzecky A, Martinkova V, Rokyta R Jr., Kralova H, Treska V, Radermacher P, Novak I: Selective inducible nitric oxide synthase inhibition during long-term hyperdynamic porcine bacteremia. Shock 2004 21:458-465

13. Enkhbaatar P, Murakami K, Traber LD, Cox R, Parkinson JF, Westphal M, Esechie A, Morita N, Maybauer MO, Maybauer DM, Burke AS, Schmalstieg FC, Hawkins HK, Herndon DN, Traber DL: The inhibition of inducible nitric oxide synthase in ovine sepsis model. Shock 2006, 25:522-527.

14. Su F, Huang H, Kazuki A, Occhipinti G, Donadello K, Piagnarelli M, De Backer $D$, Vincent $\mathrm{J}$ : Effects of a selective iNOS inhibitor versus norepinephrine in the treatment of septic shock. Shock 2010 Feb 10. [Epub ahead of print].

15. Enkhbaatar $P$, Lange M, Nakano Y, Hamahata A, Jonkam C, Wang J, Jaroch S,
Traber LD, Herndon DN, Traber DL: Role of neuronal nitric oxide synthase in ovine sepsis model. Shock 2009, 32:253-257.

16. Lange M, Connelly R, Traber DL, Hamahata A, Cox RA, Nakano Y, Bansai K, Esechie A, von Borzyskowski S, Jonkam C, Traber LD, Hawkins HK, Herndon DN, Enkhbaatar P: Combined neuronal and inducible nitric oxide synthase inhibition in ovine acute lung injury. Crit Care Med 2009, 37:223-229.

17. Matejovic M, Krouzecky A, Rokyta R Jr., Radej J, Kralova H, Treska V, Radermacher P, Novak I: Effect of combining inducible nitric oxide synthase inhibitor and radical scavenger during porcine bacteremia. Shock 2007, 27:61-68.

18. Barth E, Radermacher P, Thiemermann C, Weber S, Georgieff M, Albuszies G: Role of iNOS in the reduced responsiveness of the myocardium to catecholamines in a hyperdynamic, murine model of septic shock. Crit Care Med 2006, 34:307-313.

doi:10.1186/cc9219

Cite this article as: Hauser $B$, Radermacher P: Right man, right time, right place? - On the time course of the mediator orchestra in septic shock. Critical Care 2010, 14:190. 